\title{
Polymorphism of the osteopontin gene and clinical course of multiple sclerosis in the Polish population
}

\author{
Justyna Biernacka-Lukanty,2, Grazyna Michalowska-Wender ${ }^{1,2,3}$, Slawomir Michalak ${ }^{2,3,4}$, Beata Raczak ${ }^{1,2}$, \\ Wojciech Kozubski ${ }^{2}$, Dariusz Urbanski ${ }^{5}$, Mieczyslaw Wender ${ }^{3}$ \\ ${ }^{1}$ Laboratory of Neurogenetics, Department of Neurology, Poznan University of Medical Sciences, Poznan, ${ }^{2}$ Department of Neurology, \\ Poznan University of Medical Sciences, Poznan, ${ }^{3}$ Neuroimmunological Unit, Mossakowski Medical Research Centre Polish Academy \\ of Science, Poznan, ${ }^{4}$ Department of Neurochemistry and Neuropathology, Poznan University of Medical Sciences, Poznan, \\ ${ }^{5}$ Neuropsychiatric Hospital, Department of Neurology, Koscian, Poland
}

DOI: $10.5114 / f n .2015 .56548$

\begin{abstract}
Osteopontin (OPN) is a key cytokine involved in T-cell activation in multiple sclerosis (MS). We investigated whether polymorphism of the osteopontin gene affects MS occurrence and clinical course in a Polish population. Disability in 100 MS patients was evaluated using the Expanded Disability Status Scale (EDSS). Genotype and allele frequencies at exons 6 and 7 were examined by PCR. Using appropriate statistical tests, the distribution of variables was tested and means \pm SD compared.

Genotype distribution and allele frequency differences between patients and control individuals were not statistically significant. No association of OPN with susceptibility to MS was found in the Polish population. The EDSS score was higher in $8090 \mathrm{~T} / T+9250 \mathrm{C} / \mathrm{C}$ patients than in $8090 \mathrm{C} / \mathrm{C}+9250 \mathrm{C} / \mathrm{C}$ MS patients $(p=0.0120)$, and the disability in $8090 \mathrm{C} / \mathrm{C}+9250 \mathrm{C} / \mathrm{T}$ MS patients was higher than in $8090 \mathrm{C} / \mathrm{C}+9250 \mathrm{C} / \mathrm{C}$ MS patients $(p=0.0137)$. Logistic regression analysis revealed age to be an independent factor influencing disability.

The polymorphisms of the OPN gene in positions $8090 \mathrm{~T} / T+9250 \mathrm{C} / \mathrm{C}, 8090 \mathrm{C} / \mathrm{C}+9250 \mathrm{C} / \mathrm{T}$, and $8090 \mathrm{C} / \mathrm{T}+9250 \mathrm{C} / \mathrm{T}$ were linked with higher levels of disability in MS patients.
\end{abstract}

Key words: gene, multiple sclerosis, osteopontin, polymorphism.

\section{Introduction}

Osteopontin (OPN) is one of the key cytokines involved in T-cell activation in multiple sclerosis (MS). The OPN gene is therefore recognized as an early T-cell activation gene, which underlies immunological events involved in the aetiopathogenesis of MS [15]. In an earlier study, we found OPN to be a use- ful marker to differentiate between malignant and benign ovarian tumours [10]. In patients with optic neuritis, cerebrospinal fluid (CSF) OPN levels have been shown to be correlated with CSF chitinase-3like protein 1, myelin basic protein, and neurofilament, light polypeptide [9]. OPN also enhances the production of interleukin 12 and interferon gamma, 
and reduces interleukin 10 [8]. Moreover, OPN is expressed in MS plaques in the central nervous system [3].

During the course of MS, autoimmune inflammatory processes and associated neurodegeneration develop. The most frequent course of MS is the relapsing-remitting form, but what defines the clinical severity and duration of intervals between the relapses remains unclear. Cerebrospinal fluid OPN concentration is reported to increase during relapse and normalize during remission in MS patients [16]. In a Japanese population, plasma OPN level was used as a marker of disease activity in MS and neuromyelitis optica [14]. However, circulating OPN did not act as a marker of MS activity in participants of the Comprehensive Longitudinal Investigation of MS (CLIMB) study [7]. The important question is whether the above-mentioned discrepancies are associated with genetic factors (such as polymorphisms of cytokine genes, including $O P N$ ), environmental factors, or both. Genome screening tests for MS

Table I. Frequency of OPN genotypes in multiple sclerosis (MS) patients compared to controls

\begin{tabular}{|c|c|c|c|}
\hline Position & & $\begin{array}{c}\text { Control group } \\
n=50(\%)\end{array}$ & $\begin{array}{l}\text { MS patients } \\
n=102(\%)\end{array}$ \\
\hline \multirow[t]{7}{*}{8090} & Genotype & & \\
\hline & $\mathrm{C} / \mathrm{C}$ & $18(36)$ & $28(27)$ \\
\hline & $\mathrm{C} / \mathrm{T}$ & $5(10)$ & $22(22)$ \\
\hline & $T / T$ & $27(54)$ & $52(51)$ \\
\hline & Allele & & \\
\hline & $C$ & $41(41)$ & 79 (39) \\
\hline & $T$ & $59(59)$ & $125(61)$ \\
\hline \multirow[t]{7}{*}{9250} & Genotype & & \\
\hline & $\mathrm{C} / \mathrm{C}$ & $29(58)$ & $55(54)$ \\
\hline & $\mathrm{C} / \mathrm{T}$ & $18(36)$ & $39(38)$ \\
\hline & $T / T$ & $3(6)$ & $8(8)$ \\
\hline & Allele & & \\
\hline & $C$ & $76(76)$ & $149(73)$ \\
\hline & $T$ & $24(24)$ & $55(26)$ \\
\hline $8090 \mathrm{C} / \mathrm{C}$ & $9250 \mathrm{C} / \mathrm{C}$ & $4(8)$ & $5(4.90)$ \\
\hline $8090 \mathrm{C} / \mathrm{T}$ & $9250 \mathrm{C} / \mathrm{C}$ & $1(2)$ & $7(6.86)$ \\
\hline $8090 \mathrm{~T} / \mathrm{T}$ & $9250 \mathrm{C} / \mathrm{C}$ & $24(48)$ & $43(42.15)$ \\
\hline $8090 \mathrm{C} / \mathrm{C}$ & $9250 \mathrm{C} / \mathrm{T}$ & $12(24)$ & $16(15.68)$ \\
\hline $8090 \mathrm{C} / \mathrm{T}$ & $9250 \mathrm{C} / \mathrm{T}$ & $4(8)$ & $14(13.72)$ \\
\hline $8090 \mathrm{~T} / \mathrm{T}$ & $9250 \mathrm{C} / \mathrm{T}$ & $2(4)$ & $9(8.82)$ \\
\hline $8090 \mathrm{C} / \mathrm{C}$ & $9250 \mathrm{~T} / \mathrm{T}$ & $2(4)$ & $7(6.86)$ \\
\hline $8090 \mathrm{C} / \mathrm{T}$ & $9250 \mathrm{~T} / \mathrm{T}$ & $0(0)$ & $1(0.98)$ \\
\hline $8090 \mathrm{~T} / \mathrm{T}$ & $9250 \mathrm{~T} / \mathrm{T}$ & $1(2)$ & $0(0)$ \\
\hline
\end{tabular}

support its multifactorial aetiology, including both various genetic and environmental factors and interactions thereof $[5,13]$.

The polymorphisms of $O P N$ demonstrate variable differences among patients, as well as among various populations, necessitating further studies on this complex issue. We investigated the association, if any, of single-nucleotide polymorphisms (SNPs) of the OPN gene with MS course and severity in a Polish population.

\section{Material and methods}

We recruited 102 MS patients (25 men and 77 women; mean age, $39.0 \pm 10.0$ years) of Caucasian origin and Polish ethnicity. MS diagnosis was based on the revised McDonald criteria [12]. Two MS patients presenting with the optic-spinal form were excluded from the study, making the final number of MS participants 100. The EDSS index was established according to the Kurtzke Functional Systems Scores. A control group comprising 50 healthy blood donors, matched for age (mean $30 \pm 6.0$ years) and ethnicity, was also recruited.

All the study participants provided their informed consent. Blood samples were obtained for DNA extraction from peripheral blood cells, and genotype and allele frequencies in exons 6 and 7 were examined using specific primers in a standard PCR as presented in the paper of Niino et al. [11].

The distribution of variables (sex, age, and genotype categories) was tested with the D'Agostino-Pearson test. Mean \pm SD values were compared by the $\chi^{2}$ test. Statistical analysis was performed by one-way ANOVA, Mann-Whitney test, and logistic regression. Differences were considered statistically significant at $p<0.05$.

The study was approved by the Poznan University of Medical Sciences Committee on Human Research.

\section{Results}

Genotype distribution and allele frequencies differed between patients and control individuals, but the differences were not statistically significant. Compared to the control group, MS patients have a higher frequency of the $8090 \mathrm{C} / \mathrm{T}$ (exon 6) +9250 C/C (exon 7) OPN genotype ( $p=0.0732$; Table I). The heterozygous $C / T$ genotype at position 8090 was detected in $21.6 \%$ of patients and in $10 \%$ of control individuals. Our results showed no indication of the 
role of $O P N$ in susceptibility to MS in the Polish individuals analysed.

However, we identified $8090 \mathrm{~T} / \mathrm{T}+9250 \mathrm{C} / \mathrm{C}$, $8090 \mathrm{C} / \mathrm{C}+9250 \mathrm{C} / \mathrm{T}$, and $8090 \mathrm{C} / \mathrm{T}+9250 \mathrm{C} / \mathrm{T}$ OPN genotypes as being associated with a higher disability in MS patients compared to other genotypes (Table II).

No differences for age between genotype categories were found. However, patients with EDSS scores exceeding 2 points were significantly older (41, 34-48 years; median, interquartile range) than subjects with minor disability ( $<2$ points) $(34,28-42.75$ years) $(p=0.0162)$. Logistic regression analysis of the effect of variables on EDSS scoring in the model, including sex, age, and genotype categories, revealed age to be an independent factor influencing disability $(p=0.0140)$.

\section{Discussion}

The role of OPN in inflammatory diseases, including MS, has been demonstrated in several studies. The polymorphisms of the OPN gene have been established to be associated with MS in Japanese patients [11]. However, these findings could not be replicated in Caucasian MS patients; for instance, the 795 CT polymorphism in the OPN gene was not found to be associated with MS in a Spanish population [8]. In our study on a Polish Caucasian population, the heterozygous C/T genotype at positions 8090 and 9250 tended to have a higher frequency in MS patients compared to the control group. Similar findings were obtained for genotype frequencies of $\mathrm{C} / \mathrm{C}$ and $\mathrm{TT}$ and allele frequencies of $\mathrm{C}$ and $\mathrm{CT}$. Thus, haplotype structure might differ across populations. It is not easy to link the differences between Asian and European $O P N$ polymorphisms with differences in prevalence rates in the corresponding geographical regions. MS incidence in Japan and other Asian countries is lower than in Europe and North America. Therefore, determining an association of polymorphisms of $O P N$ with susceptibility to MS is not that simple.

Several studies provide conflicting results on the impact of OPN gene variations on MS severity. Caillier et al. found that patients carrying at least one wild-type $1284 \mathrm{~A} / 4$ allele were less likely to have a mild disease course [2]. Hensiek et al. found no effect of SNPs located in exons 6 and 7 of OPN on the clinical severity of MS [6], while Comi et al. reported the role of OPN variation on MS development and progression; however, they did not discuss its effect on disease severity [4].

An interesting point was presented in experimental allergic encephalomyelitis by Begum-Haque et al. [1]. The authors found that glatiramer acetate biased dendritic cells towards an anti-inflammatory phenotype by modulating OPN, IL-7 and RORyt responses and by increasing IL-10 production. The issue should also be studied in MS patients.

Table II. Disability measure in studied subgroups of multiple sclerosis (MS) patients

\begin{tabular}{|c|c|c|}
\hline Studied group & EDSS score (median; interquartile range) & $p$ \\
\hline Total, $n=102$ & $3.0 ; 2.00-4.00$ & N/A \\
\hline Females, $n=77 /$ males, $n=25$ & $3.00 ; 2.00-4.25 / 3.25 ; 2.00-4.00$ & 0.8743 \\
\hline $8090 \mathrm{C} / \mathrm{C}+9250 \mathrm{C} / \mathrm{C}, n=4$ & $1.75 ; 1.50-2.00$ & As below \\
\hline $8090 \mathrm{C} / \mathrm{T}+9250 \mathrm{C} / \mathrm{C}, n=7$ & $2.00 ; 1.50-2.50$ & As below \\
\hline $8090 \mathrm{~T} / \mathrm{T}+9250 \mathrm{C} / \mathrm{C}, n=43$ & $3.00 ; 2.00-4.00$ & $\begin{array}{c}0.0120 \text { vs. } 8090 \mathrm{C} / \mathrm{C}+9250 \mathrm{C} / \mathrm{C} \\
\text { and } \\
0.0482 \text { vs. } 8090 \mathrm{C} / \mathrm{T}+9250 \mathrm{C} / \mathrm{C}\end{array}$ \\
\hline $8090 \mathrm{C} / \mathrm{C}+9250 \mathrm{C} / \mathrm{T}, n=16$ & $3.75 ; 2.50-4.50$ & $\begin{array}{c}0.0137 \text { vs. } 8090 \mathrm{C} / \mathrm{C}+9250 \mathrm{C} / \mathrm{C} \\
\text { and } \\
0.0482 \text { vs. } 8090 \mathrm{C} / \mathrm{T}+9250 \mathrm{C} / \mathrm{C}\end{array}$ \\
\hline $8090 \mathrm{C} / \mathrm{T}+9250 \mathrm{C} / \mathrm{T}, n=14$ & $3.25 ; 2.50-5.00$ & 0.0553 vs. $8090 \mathrm{C} / \mathrm{C}+9250 \mathrm{C} / \mathrm{C}$ \\
\hline $8090 \mathrm{~T} / \mathrm{T}+9250 \mathrm{C} / \mathrm{T}, n=9$ & $2.50 ; 1.38-4.25$ & N.S. \\
\hline $8090 \mathrm{C} / \mathrm{C}+9250 \mathrm{~T} / \mathrm{T}, n=6$ & $4.00 ; 3.00-5.50$ & N.S. \\
\hline $8090 \mathrm{C} / \mathrm{T}+9250 \mathrm{~T} / \mathrm{T}, n=1$ & 2.0 & N/A \\
\hline
\end{tabular}

N.S. - not significant, N/A - not applicable - insufficient data 
To conclude, in our study, we identified $8090 \mathrm{~T} / \mathrm{T}$ + $9250 \mathrm{C} / \mathrm{C}, 8090 \mathrm{C} / \mathrm{C}+9250 \mathrm{C} / \mathrm{T}$, and $8090 \mathrm{C} / \mathrm{T}+$ $9250 \mathrm{C} / \mathrm{T}$ OPN to be associated with higher levels of disability in MS patients compared to other genotypes. Although we could not establish an association of OPN polymorphisms with MS susceptibility in a population of Polish patients, our results provide a line of evidence on the impact of $O P N$ variations on the course of MS. Overall, the differential effects of various combinations of variants in genotypes may contribute to explaining the differences in MS susceptibility between ethnic groups and disability in individual patients. Thus, further research in other populations is needed as well as evaluation of disease severity related to OPN gene polymorphism in single subjects.

\section{Disclosure}

Authors report no conflict of interest.

\section{References}

1. Begum-Haque S, Christy M, Wang Y, Kasper E, Ochoa-Reparaz J, Smith JY, Haque A, Kasper LH. Glatiramer acetate biases dendritic cells towards an anti-inflammatory phenotype by modulating OPN, IL-17, and ROR $\gamma$ t responses and by increasing IL-10 production in experimental allergic encephalomyelitis. J Neuroimmunol 2013; 254 (1-2): 117-124.

2. Caillier S, Barcellos LF, Baranzini SE, Swerdlin A, Lincoln RR, Steinman L, Martin E, Haines JL, Pericak-Vance M, Hauser SL, Oksenberg JR. Multiple Sclerosis Genetics Group. Osteopontin polymorphisms and disease course in multiple sclerosis. Genes Immun 2003; 4: 312-315.

3. Chabas D, Baranzini SE, Mitchell D, Bernard CC, Rittling SR, Denhardt DT, Sobel RA, Lock C, Karpuj M, Pedotti R, Heller R, Oksenberg JR, Steinman $L$. The influence of the proinflammatory cytokine, osteopontin, on autoimmune demyelinating disease. Science 2001; 294: 1731-1735.

4. Comi C, Cappellano G, Chiocchetti A, Orilieri E, Buttini S, Ghezzi L, Galimberti D, Guerini F, Barizzone N, Perla F, Leone M, D’Alfonso S, Caputo D, Scarpini E, Cantello R, Dianzani U. The impact of osteopontin gene variations on multiple sclerosis development and progression. Clin Dev Immunol 2012; 2012: 212893.

5. Haines JL, Ter-Minassian M, Bazyk A, Gusella JF, Kim DJ, Terwedow H, Pericak-Vance MA, Rimmler JB, Haynes CS, Roses AD, Lee A, Shaner B, Menold M, Seboun E, Fitoussi RP, Gartioux C, Reyes C, Ribierre F, Gyapay G, Weissenbach J, Hauser SL, Goodkin DE, Lincoln R, Usuku K, Oksenberg JR, et al. A complete genomic screen for multiple sclerosis underscores a role for the major histocompatability complex. The Multiple Sclerosis Genetics Group. Nat Genet 1996; 13: 469-471.

6. Hensiek AE, Roxburgh R, Meranian M, Seaman S, Yeo T, Compston DA, Sawcer SJ. Osteopontin gene and clinical severity of multiple sclerosis. J Neurol 2003; 250: 943-947.
7. Kivisäkk P, Healy BC, Francois K, Gandhi R, Gholipour T, Egorova S, Sevdalinova V, Quintana F, Chitnis T, Weiner HL, Khoury SJ. Evaluation of circulating osteopontin levels in an unselected cohort of patients with multiple sclerosis: relevance for biomarker development. Mult Scler 2014; 20: 438-444.

8. Mas A, Martínez A, de las Heras V, Bartolomé M, de la Concha EG, Arroyo R, Urcelay E. The $795 \mathrm{CT}$ polymorphism in osteopontin gene is not associated with multiple sclerosis in a Spanish population. Mult Scler 2007; 13: 250-252.

9. Modvig S, Degn M, Horwitz H, Cramer SP, Larsson HB, Wanscher B, Sellebjerg F, Frederiksen JL. Relationship between cerebrospinal fluid biomarkers for inflammation, demyelination and neurodegeneration in acute optic neuritis. PLoS One 2013; 8: e77163.

10. Moszyński R, Szubert S, Szpurek D, Michalak S, Sajdak S. Role of osteopontin in differential diagnosis of ovarian tumors. J Obstet Gynaecol Res 2013; 39: 1518-1525.

11. Niino M, Kikuchi S, Fukazawa T, Yabe I, Tashiro K. Genetic polymorphisms of osteopontin in association with multiple sclerosis in Japanese patients. J Neuroimmunol 2003; 136: 125-129.

12. Polman CH, Reingold SC, Banwell B, Clanet M, Cohen JA, Filippi M, Fujihara K, Havrdova E, Hutchinson M, Kappos L, Lublin FD, Montalban X, O'Connor P, Sandberg-Wollheim M, Thompson AJ, Waubant E, Weinshenker B, Wolinsky JS. Diagnostic criteria for multiple sclerosis: 2010 revisions to the McDonald criteria. Ann Neurol 2011; 69: 292-302.

13. Sawcer S, Jones HB, Feakes R, Gray J, Smaldon N, Chataway J, Robertson N, Clayton D, Goodfellow PN, Compston A. A genome screen in multiple sclerosis reveals susceptibility loci on chromosome 6p21 and 17q22. Nat Genet 1996; 13: 464-468.

14. Shimizu Y, Ota K, Ikeguchi R, Kubo S, Kabasawa C, Uchiyama S. Plasma osteopontin levels are associated with disease activity in the patients with multiple sclerosis and neuromyelitis optica. J Neuroimmunol 2013; 263: 148-151.

15. Steinman L, Zamvil S. Transcriptional analysis of targets in multiple sclerosis. Nat Rev Immunol 2003; 3: 483-492.

16. Szalardy L, Zadori D, Simu M, Bencsik K, Vecsei L, Klivenyi P. Evaluating biomarkers of neuronal degeneration and neuroinflammation in CSF of patients with multiple sclerosis - osteopontin as a potential marker of clinical severity. J Neurol Sci 2013; 331: 38-42. 